\title{
PCR-Based Detection of Cephalosporium gramineum in Winter Wheat
}

K. L. E. Klos, Department of Plant Pathology, Washington State University, Pullman 99164-6430; L. M. Vásquez-Siller, Centro de Capacitación y Desarrollo en Tecnología de Semillas (CCDTS), Departamento de Fitomejoramiento, Universidad Autónoma Agraria Antonio Narro, Calzada Antonio Narro 1923, Buenavista, C.P. 25315, Saltillo, Coahuila, México; and H. C. Wetzel, III and T. D. Murray, Department of Plant Pathology, Washington State University, Pullman

\begin{abstract}
Klos, K. L. E., Vásquez-Siller, L. M., Wetzel, H. C., III, and Murray, T. D. 2012. PCR-based detection of Cephalosporium gramineum in winter wheat. Plant Dis. 96:437-442.

A polymerase chain reaction (PCR) assay was developed amplifying a 496-bp fragment of the internal transcribed spacer region of Cephalosporium gramineum genomic DNA at concentrations of $100 \mathrm{fg} / \mu \mathrm{l}$. Winter wheat seed and seedlings were collected from field plots where C. gramineum was present. Seed was tested by PCR using 20-seed samples bulked for DNA extraction. Estimates of seed infection, based on isolation of the pathogen on semiselective medium and PCR, were comparable at 0.18 and $0.13 \%$ of winter wheat 'Stephens' $(P=$ $0.6042)$, and 0.45 and $0.58 \%$ of experimental line WA7970 $(P=$ $0.5636)$, respectively. PCR differentiated between plants with well-

developed symptoms of Cephalosporium stripe and noninoculated plants. Positive PCR was obtained from $22 \%$ of asymptomatic leaf blades from inoculated plants. We found no false positives when PCR and C. gramineum isolation on a semiselective medium were performed using tissue from the same leaf. The PCR assay has potential to diagnose Cephalosporium stripe disease prior to the appearance of symptoms. Negative PCR for some samples from which $C$. gramineum was isolated suggests that $C$. gramineum may be present below the level of detection in some asymptomatic leaves. This PCR assay may be useful for investigations into C. gramineum infection of wheat.
\end{abstract}

The soilborne fungus Cephalosporium gramineum Y. Nisik. \& Ikata causes Cephalosporium stripe, a vascular wilt disease of wheat and other grasses. C. gramineum is a widespread pathogen in the United States and other wheat-producing countries where winter wheat is subjected to snow cover and frozen soil. Cephalosporium stripe has been reported is several U.S. states where it occurs sporadically; however, it is a widespread, chronic disease in the wheat-growing region of eastern Washington State $(6,7,12)$.

Infection of winter wheat (Triticum aestivum L.) by $C$. gramineum is thought to occur mainly during winter and early spring via root injury due to freeze stress and frost heaving $(4,25)$. Crown roots appear to be the primary infection site, and the pathogen colonizes adjacent stems through the crown tissues $(14,26)$. $C$. gramineum also penetrates and colonizes stems through the leaf sheath epidermis or wounds where tillers emerge (8).

Following infection, conidia are spread systemically through the xylem vessels $(1,19,29)$. Diseased wheat tillers have long yellowish stripes on the leaf blades, with stripes continuing on the leaf sheaths (7). Diseased plants may exhibit shorter culms, small heads, and light-weight shrunken kernels compared with healthy plants $(6,7,13)$. With severe disease, yield losses in winter wheat range from 25 to $100 \%(13,22)$, largely due to reduced seed weight and number per head rather than number of heads (11).

Seed of infected tillers may become infected. Bruehl (7) found a seed infection rate of 5 per 587 kernels $(0.9 \%)$ when stems were hypodermically inoculated. In seed harvested from winter wheat plots where Cephalosporium stripe was present, $C$. gramineum isolation rates of 0.1 to $7.3 \%$ have been reported $(2,5,16)$. Both

Corresponding author: T. Murray, E-mail: tim_murray@wsu.edu

Plant Pathology New Series Number 0575; and College of Human, Agricultural, and Natural Resource Sciences Agricultural Research Center Project number 0670, Washington State University.

Accepted for publication 26 October 2011.

http://dx.doi.org/10.1094/PDIS-07-11-0568

(C) 2012 The American Phytopathological Society severely diseased and symptomless plants may produce seed infected with $C$. gramineum (16).

The most rapid method of diagnosing Cephalosporium stripe is by the visual symptoms. However, invasion of the xylem vessels precedes yellowing by 5 to 7 days (29) and isolation of $C$. gramineum from the seed of exposed but apparently healthy plants demonstrates that infection may be present without visual symptoms (16). In addition, other factors result in formation of stripes in leaves that may resemble symptoms of Cephalosporium stripe. Confirming the presence of $C$. gramineum in affected plant tissues requires a 10 - to 15 -day incubation period prior to visual inspection of colonies. A polymerase chain reaction (PCR)-based assay that improves both the speed and accuracy of diagnosis would be a useful research tool for investigating $C$. gramineum infection in wheat.

The region of the $C$. gramineum genome containing ribosomal RNA genes $18 \mathrm{~S}, 5.8 \mathrm{~S}$ and $28 \mathrm{~S}$, and the internal transcribed spacer (ITS) has been characterized at the sequence level (23). This region is a good candidate for the development of species-specific PCRbased assays because of the high degree of variability among species and conservation within species $(10,28)$. Baaj and Kondo (3) recently developed a PCR assay specific to $C$. gramineum using the intergenic spacer (IGS) of rDNA. Their assay selectively amplified an approximately 1,880-bp product without amplification in other fungi or in mock-inoculated wheat. However, the utility of that method for investigations of $C$. gramineum seed infection was not evaluated, nor was it characterized for sensitivity at various stages of wheat development or compared against existing diagnostic tools. The goal of this project was to develop a PCR-based assay capable of detecting $C$. gramineum genomic DNA in winter wheat tissue and to assess its utility as a research tool for investigations of seed and plant infection.

\section{Materials and Methods}

Primer design and PCR conditions. Multiple global alignment of the ITS 1 and ITS 2 sequences of $C$. gramineum, Phialophora gregata, and Rhynchosporium secalis (selected based on $94 \%$ similarity to $C$. gramineum using the National Center of Biotechnology Information BLAST program) was performed to identify potential primer sequences for species-specific amplification. Designed primer pairs were evaluated for their ability to amplify genomic 
DNA fragments of the expected size from 22 isolates of $C$. gramineum and compared for the minimum concentration of template DNA required for amplification (27). The primer pair $5^{\prime}$ GTCGTTCGTGTAGGGGCAA-3' (CGF) and 5'-CTGATCCGA GGTCAACCTGT-3' (CGR) was selected for optimization.

PCR conditions were optimized for the selected primer pair by creating a matrix of parameters and evaluating combinations for the ability to correctly differentiate severely infected wheat leaf tissue from tissue of plants with no exposure to $C$. gramineum. The parameters evaluated were GoTaq (Promega Corporation, Madison, WI) or TaKaRa Ex Taq (Takara Bio Inc., Otsu, Shiga, Japan) DNA polymerase; $\mathrm{MgCl}_{2}$ at 2, 2.5, or $3 \mathrm{mM} ; 800$ or $80 \mathrm{ng}$ of total plant nucleic acids; and the addition of $15,000 \mathrm{ng}$ of bovine serum albumin (BSA) in a 50- $\mu$ l mixture. The PCR program was held constant with an initial denaturation step of $94^{\circ} \mathrm{C}$ for $3 \mathrm{~min} ; 35$ cycles of denaturation at $94^{\circ} \mathrm{C}$ for $30 \mathrm{~s}$, annealing at $60^{\circ} \mathrm{C}$ for $30 \mathrm{~s}$, and elongation at $72^{\circ} \mathrm{C}$ for $1 \mathrm{~min}$; then a final elongation step at $72^{\circ} \mathrm{C}$ for $5 \mathrm{~min}$. The best reaction mixture was further optimized by evaluating amplification using the same PCR program but with an annealing temperature gradient from 56 to $69^{\circ} \mathrm{C}$. Unknown samples were run at a final reaction mix of $50 \mu \mathrm{l}(1.25 \mathrm{U}$ of Takara Ex Taq DNA polymerase, $1 \times$ buffer, $3 \mathrm{mM} \mathrm{MgCl}_{2}, 0.2 \mathrm{mM} \mathrm{dNTP}$ mix, $1.2 \mu \mathrm{M}$ each primer, and 10 to $100 \mathrm{ng}$ of DNA) in 35 cycles of three-step PCR with an annealing temperature of $65^{\circ} \mathrm{C}$. Amplification products were run on a $1.2 \%$ agarose gel containing Syber Safe DNA gel stain (Invitrogen, Carlsbad, CA) at a constant $120 \mathrm{~V}$ for approximately $45 \mathrm{~min}$.

DNA extraction. Five DNA extraction protocols were compared for the ability to extract total nucleic acids from eight samples of leaf tissue each from mildly symptomatic winter wheat 'Stephens' and asymptomatic breeding line J99C0009 taken from 2008 field plots: (i) DNeasy Plant Mini Kit (Qiagen Inc., Valencia, CA) with approximately $0.05 \mathrm{~g}$ of leaf tissue mechanically crushed in liquid nitrogen; (ii) a salting-out method modified from Presting et al. (20) and Weising et al. (30) as described below, with mechanical crushing of approximately $0.1 \mathrm{~g}$ of leaf tissue in liquid nitrogen and a 15 -min incubation at $65^{\circ} \mathrm{C}$ for cell lysis; (iii) the salting-out protocol with mechanical crushing of an average of $0.02 \mathrm{~g}( \pm 0.004 \mathrm{~g})$ of leaf tissue in liquid nitrogen but a 60 -min incubation at $65^{\circ} \mathrm{C}$ for cell lysis; (iv) the salting-out protocol with an average of $0.03 \mathrm{~g}( \pm 0.01 \mathrm{~g})$ of leaf tissue disrupted on a Mini Bead-Beater (Biospec Products, Inc., Bartlesville, OK) for 3 min using $800 \mu \mathrm{M}$ silicon beads in the buffer solution and an incubation of $60 \mathrm{~min}$ for cell lysis; and (v) the salting-out protocol with an average of $0.02 \mathrm{~g}( \pm 0.008 \mathrm{~g})$ of leaf tissue disrupted on a Mini Bead-Beater for 5 min using $800 \mu \mathrm{M}$ silicon beads in the buffer solution and an incubation of $60 \mathrm{~min}$ for cell lysis. Protocols were evaluated for total nucleic acids yield in micrograms and for consistency of PCR score within variety.

For unknown samples, DNA was extracted from an average of $0.1( \pm 0.05) \mathrm{g}$ of lyophilized mycelium or conidia, $0.09( \pm 0.03) \mathrm{g}$ of leaf tissue mechanically crushed in liquid nitrogen, or an 0.16 $( \pm 0.02)$-g sample from 20 seeds finely ground using a spice grinder by the salting-out method as follows. Tissue was added to $1 \mathrm{ml}$ of buffer (100 mM Tris-HCL [pH 8], $0.5 \mathrm{mM}$ EDTA, $500 \mathrm{mM} \mathrm{NaCl}$, and $10 \mathrm{mM} \beta$-mercaptoethanol) and $140 \mu \mathrm{l}$ of $10 \%$ sodium dodecyl sulfate and vortexed to mix. Samples were incubated for $60 \mathrm{~min}$ at $65^{\circ} \mathrm{C}$ before adding $250 \mu \mathrm{l}$ of $8 \mathrm{M}$ potassium acetate and holding on ice for $10 \mathrm{~min}$. Total nucleic acids were precipitated from supernatant in isopropanol on ice, washed in $70 \%$ ethanol, then suspended in sterile distilled water. DNA concentration was estimated using a Nanodrop 1000 spectrophotometer (Thermo Scientific, Inc., West Palm Beach, FL). DNA quality was evaluated by visualization under ultraviolet light after running across a 1.2\% agarose gel containing Syber Safe DNA gel stain at a constant $120 \mathrm{~V}$ for approximately $45 \mathrm{~min}$.

Cultural practices. Winter wheat samples were collected from experimental field plots located at the Palouse Conservation Field Station near Pullman, WA in the 2007-08, 2008-09, and 2009-10 growing seasons (hereafter called 2008, 2009, and 2010). These plots were established to evaluate winter wheat cultivars and breed- ing lines for their reaction to Cephalosporium stripe $(31,32)$ and were inoculated with oat kernels colonized by $C$. gramineum in October of each planting year $(213 \mathrm{~kg} / \mathrm{ha})$. These plots are managed in a 3-year rotation, with winter wheat planted once in the crop cycle to minimize inoculum carryover from previous experiments. Other cultural practices were consistent with local commercial practices.

Plant sampling and disease incidence. In 2008, seed harvested from winter wheat Stephens and breeding line WA7970 were surface disinfected as described below. Individual DNA extracts from 500 seeds were evaluated for the presence of $C$. gramineum by PCR as described above to differentiate infected from uninfected seed. A preliminary detection threshold was estimated by evaluating amplification of DNA from a single positive seed diluted 1:10, $1: 100$, and $1: 1000$ into DNA (300 $\mathrm{ng} / \mu \mathrm{l})$ from healthy seed. PCR detection of $C$. gramineum in seed lots with unknown rates of infection was performed by dividing four replicates of 1,000 seeds into 20-seed lots for DNA extraction (50 extracts per replicate). These data were compared with data from the existing method of C. gramineum detection, which consists of four replicates of 1,000 seeds tested by isolation on a semiselective medium (described below). Estimates of infected seed by PCR and by pathogen isolation were compared using a $t$ test with the SAS statistical software package (SAS 9.2; SAS Institute Inc., Cary NC).

In 2009, WA7970 and winter wheat 'Eltan', 'Hill-81', 'Madsen', and Stephens were sampled on 6 April, 20 April, 4 May, 18 May, and 1 June. Four individual plants of each cultivar were randomly sampled from a strip ( $49 \mathrm{~m}$ long by $1.4 \mathrm{~m}$ wide) bordering the cultivar experiment by carefully digging them with a shovel and washing them to remove soil. A single leaf blade was scored for presence of symptoms. Total nucleic acids were extracted from these blades according to the protocol described above. At the final three sampling dates, four additional Stephens plants were selected to serve as positive controls on the basis of severe symptoms and four Madsen plants were selected from a noninoculated part of the same field at the same growth stage to serve as negative controls. DNA was extracted from a single leaf of each plant. Fisher's exact test was used to evaluate the effects of categorical variables on measures of disease incidence.

In 2010, three symptomatic and three asymptomatic plants of Stephens and WA7970 were sampled from field plots on 15 April, 29 April, and 13 May as described previously. A single tiller from each symptomatic plant was selected on the basis of distinct symptoms. The youngest symptomatic leaf blade and the asymptomatic blade immediately above it were removed and surface disinfected as described below. In all, $1 \mathrm{~cm}$ of each blade was placed on a semiselective medium for isolation of $C$. gramineum as described below and $2 \mathrm{~cm}$ of upper leaf blade tissue was used for DNA extraction. Asymptomatic plants were treated similarly, except that tillers were selected randomly. On 26 May, six tillers of winter wheat 'Brundage 96', Eltan, 'Finch', and 'Tubbs 06' were selected on the basis of distinct symptoms and treated as above.

Fungal isolation. Seed were surface disinfected by soaking in $95 \%$ ethanol for 2 min while stirring with a magnetic stir-bar. The ethanol was decanted and seed were soaked in a $20 \%$ bleach solution for 2 min with stirring. Seed were then rinsed three times, $30 \mathrm{~s}$ each, with sterile deionized water and placed on sterile moist filter paper in 10-cm-diameter petri dishes. Seed were incubated at room temperature for $24 \mathrm{~h}$ (approximately $20^{\circ} \mathrm{C}$ ), frozen at $-20^{\circ} \mathrm{C}$ for 20 $\mathrm{h}$ to kill them (2), then placed on $C$. gramineum semiselective medium (CGSM) and incubated at $14^{\circ} \mathrm{C}$ (24). Leaf blades were surface disinfected by placing them in a $10 \%$ bleach solution for 1 min, then rinsing in sterile deionized water for $30 \mathrm{~s}$. Leaf sections were placed on CGSM and incubated at $14^{\circ} \mathrm{C}$. Samples were examined with a stereo microscope after 1 week and at weekly intervals for 1 month. Conidia were removed from fungal colonies resembling $C$. gramineum and examined with a compound microscope to confirm their identity.

Single germinating conidia of 22 isolates of $C$. gramineum originating from the leaves of symptomatic winter wheat collected from 
Asotin, Grant, and Whitman Counties of Washington State were transferred from water agar with rifampicin $(50 \mu \mathrm{g} / \mathrm{ml})$ to one of the following to establish axenic isolates for evaluating assay specificity. Subcultures for DNA extraction were grown on corn meal agar (Difco Laboratories, Detroit) at room temperature or in potato dextrose broth (Difco Laboratories) on a shaker for 6 days at room temperature when conidia were collected and washed with distilled water by centrifugation. One $C$. gramineum isolate from Geneva, NY was provided by M. Cadle-Davidson, Cornell University. Wheat seed mycoflora were isolated from seed lots collected from wheat harvested from the Palouse Conservation Field Station and Plant Pathology farms, Pullman, WA using the freeze blotter technique (17). Isolates were purified as above and cultured on sucrose nutrient agar (SNA), potato dextrose agar, V8 juice agar, and potato carrot agar $(9,18)$. Isolates were identified with morphological taxonomic keys and maintained at $4{ }^{\circ} \mathrm{C}$ or stored as lyophilized mycelium at $-20^{\circ} \mathrm{C}$ until use. P. gregata was provided by W. Chen, United States Department of AgricultureAgricultural Research Service, Washington State University (WSU), Pullman, WA. Verticillium dahliae and Oculimacula isolates were from the culture collection of the Cereal Disease Research Laboratory, WSU.

Sequence comparison. In order to confirm the identity of amplicons, bands from purified $C$. gramineum and from two randomly selected Stephens positive control plants were excised from 1.2\% agarose gels and purified using a QIAquick Gel Extraction Kit (Qiagen Inc.). The resulting purified PCR products were sequenced by the WSU Center for Reproductive Biology Molecular Biology Core laboratory. Sequences were evaluated for similarity using the Clustal X software program.
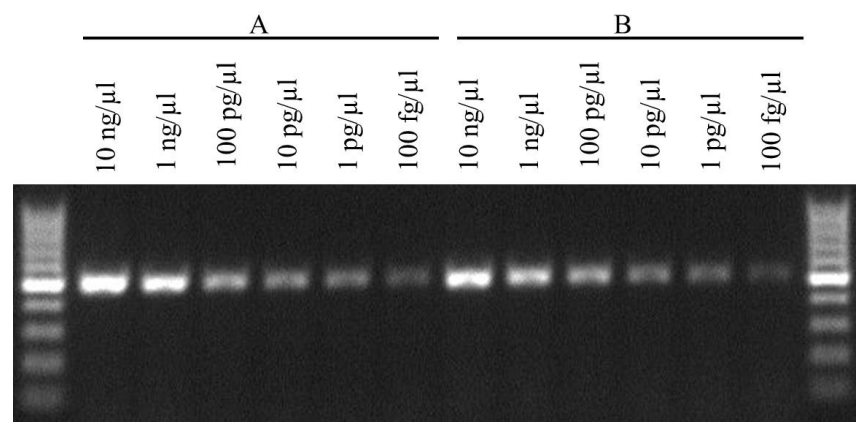

Fig. 1. Limits of detection by polymerase chain reaction of Cephalosporium gramineum DNA in wheat total nucleic acids. A, C. gramineum DNA diluted into total DNA $(300 \mathrm{ng} / \mu \mathrm{l})$ of healthy wheat leaf tissue. B, C. gramineum DNA diluted into water.

\section{Results}

Methods optimization. A 496-bp fragment was amplified from the genomic DNA of $22 C$. gramineum isolates (27). Amplification of $C$. gramineum genomic DNA was detected at concentrations as low as $100 \mathrm{fg} / \mu \mathrm{l}$ when diluted into wheat DNA at $300 \mathrm{ng} / \mu \mathrm{l}$ or into water (Fig. 1). No amplification of wheat mycoflora other than $C$. gramineum was detected at template concentrations of $2 \mathrm{ng} / \mu \mathrm{l}$ (Fig. 2). Interference by unknown compounds prevented consistent amplification by GoTaq but not by TaKaRa Ex Taq using DNA extracted from plant tissue. The addition of BSA to the GoTaq reaction mix improved repeatability, as did dilution of plant tissue extracts, by a factor of 10 (not shown).

Extraction protocols did not differ for DNA quality as evaluated by visualization on a $1.2 \%$ agarose gel (not shown). The average total nucleic acid yield across 16 samples differed among protocols $(P>0.0001)$ and was greatest using the salting-out method with mechanical disruption in liquid nitrogen of approximately $0.1 \mathrm{~g}$ of leaf tissue (Table 1). The DNeasy Kit yielded a high-quality product but neither this nor the highest yielding protocol produced extracts that met the repeatability of the other protocols (Table 1). The three protocols with a $60-\mathrm{min}$ incubation at $65^{\circ} \mathrm{C}$ for cell lysis had a higher proportion of symptomatic leaves scored positive for $C$. gramineum by PCR than did the two protocols with shorter incubation times $(P=0.0068)$.

The nucleotide sequence of amplicons from leaf blades positive for Cephalosporium stripe symptoms did not differ from that of amplicons from $C$. gramineum genomic DNA (not shown). No amplification was detected in DNA from noninoculated Madsen plants.

PCR detection of infected seed. PCR of DNA extracted from individual seed of Stephens harvested from 2008 field plots resulted in amplicons of the expected size from 1 of 500 seed (not shown). PCR was positive for C. gramineum when DNA from this seed was diluted 1:10 in DNA from healthy seed. When positive seed DNA was diluted 1:100, an amplicon was faintly visible in four of six reactions. Based on this, we elected to combine 20 seeds for DNA extraction. There were $1.25 \pm 1.5$ and $5.75 \pm 3.1$ positive PCR scores out of 50 extracts (1,000 seeds) in Stephens and WA7970, respectively. Isolation on CGSM yielded estimates of $1.75 \pm 1.5$ and $4.5 \pm 1.29$ infected seed per thousand in Stephens and WA7970, respectively. The null hypothesis that estimates from these two methods were equal was not rejected in the paired $t$ test $(P=0.6042$ in Stephens and $P=0.5636$ in WA7970).

Correlation between PCR detection and plant symptoms. Cephalosporium stripe visual disease incidence increased on all five cultivars as the 2009 growing season progressed $(P=0.0003$;

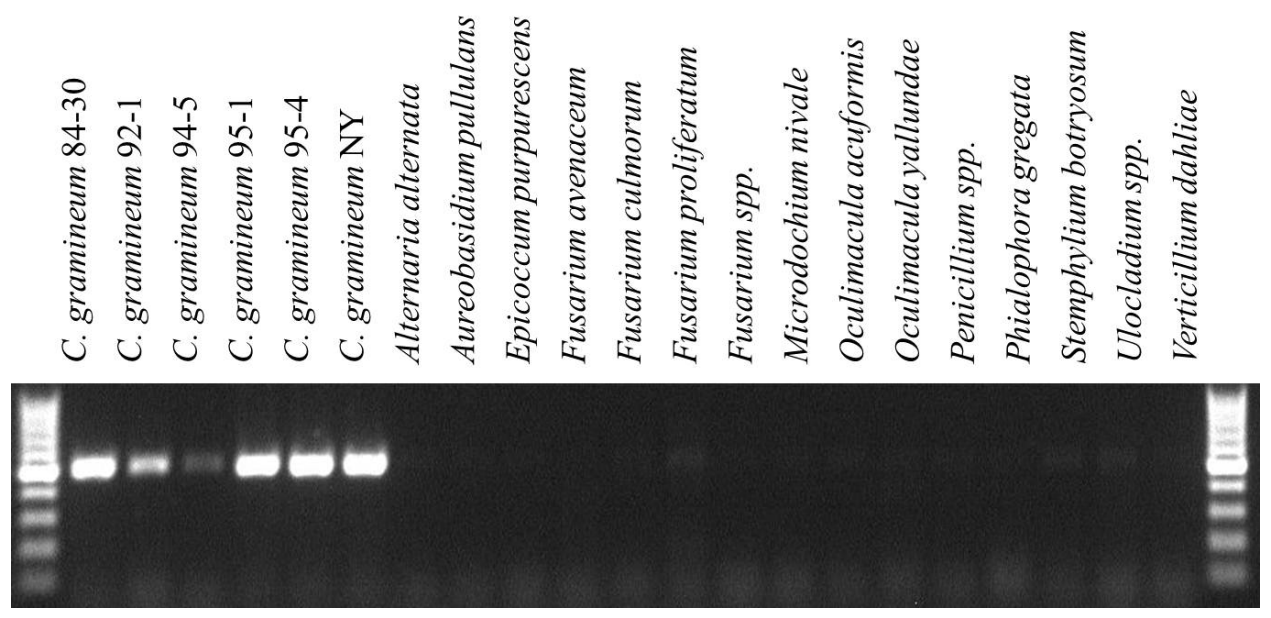

Fig. 2. Specificity of detection by polymerase chain reaction of Cephalosporium gramineum DNA compared with DNA of 15 other winter wheat mycoflora at a template concentration of $2 \mathrm{ng} / \mathrm{\mu l}$. Wheat seed mycoflora was isolated from seed lots collected from several locations in Washington State using the freeze blotter technique and purified by transfer from water agar with rifampicin $(50 \mu \mathrm{g} / \mathrm{ml})$ to sucrose nutrient agar, potato dextrose agar, V8 juice agar, or potato carrot agar to establish axenic isolates. C. gramineum isolate codes reflect year of collection and location. 
Table 2), as did the severity of symptoms on blades taken for DNA extraction. In April, visual symptoms consisted of very faint striping, with no more than a single stripe visible per leaf, except for one leaf of the highly susceptible Stephens on which stripes were well developed. By late May, leaf blades with well-developed symptoms were sampled from all five winter wheat cultivars.

Of the 100 randomly sampled plants, 45 exhibited Cephalosporium stripe symptoms. One symptomatic Eltan leaf blade sampled 1 June was scored negative for $C$. gramineum by PCR (Table 2). Two of the Stephens plants sampled 4 May were discordant for visual and PCR scores, resulting in an equal proportion of positive scores by both methods. All other symptomatic leaf blades were also scored positive for $C$. gramineum by PCR. Overall, a greater

Table 1. Mean yield (and standard deviation) of total nucleic acids and proportion of eight samples scored positive for Cephalosporium gramineum by polymerase chain reaction (PCR) for extracts from symptomatic leaves of susceptible winter wheat 'Stephens' and asymptomatic leaves of breeding line J99C0009

\begin{tabular}{lccccc}
\hline & \multicolumn{2}{c}{ Stephens } & & \multicolumn{2}{c}{ J99C0009 } \\
\cline { 2 - 3 } \cline { 5 - 6 } Protocol $^{\mathbf{a}}$ & $\begin{array}{c}\text { Yield } \\
(\boldsymbol{\mu g})\end{array}$ & $\begin{array}{c}\text { Positive } \\
\text { PCR }\end{array}$ & & $\begin{array}{c}\text { Yield } \\
(\boldsymbol{\mu g})\end{array}$ & $\begin{array}{c}\text { Positive } \\
\text { PCR }\end{array}$ \\
\hline DNeasy Kit & $10.7( \pm 12.5)$ & 0.63 & & $15.8( \pm 8.0)$ & 0.25 \\
SO LiqN 15 & $64.5( \pm 19.6)$ & 0.50 & & $74.5( \pm 23.8)$ & 0.25 \\
SO LiqN 60 & $5.3( \pm 1.2)$ & 0.88 & & $6.9( \pm 3.9)$ & 0.38 \\
SO BB 3 & $4.0( \pm 1.2)$ & 0.88 & & $2.6( \pm 1.5)$ & 0.25 \\
SO BB 5 & $4.9( \pm 2.4)$ & 0.88 & & $4.5( \pm 2.7)$ & 0.50 \\
\hline
\end{tabular}

${ }^{a}$ DNeasy Kit $=$ DNeasy Plant Mini Kit with approximately $0.05 \mathrm{~g}$ of leaf tissue mechanically crushed in liquid nitrogen; SO LiqN $15=$ a saltingout DNA extraction protocol with mechanical crushing of approximately $0.10 \mathrm{~g}$ of leaf tissue in liquid nitrogen and a 15 -min incubation at $65^{\circ} \mathrm{C}$ for cell lysis; SO LiqN $60=$ the salting out protocol with mechanical crushing of approximately $0.02 \mathrm{~g}$ of leaf tissue in liquid nitrogen and a 60 -min incubation at $65^{\circ} \mathrm{C}$; SO BB $3=$ the salting out protocol with approximately $0.03 \mathrm{~g}$ of leaf tissue disrupted on a Mini Bead-Beater for 3 min using $800 \mu \mathrm{M}$ silicon beads in the buffer solution and an incubation of $60 \mathrm{~min}$ for cell lysis; SO BB $5=$ the salting out protocol with approximately $0.02 \mathrm{~g}$ of leaf tissue disrupted on a Mini Bead-Beater for 5 min using $800 \mu \mathrm{M}$ silicon beads in the buffer solution and an incubation of $60 \mathrm{~min}$ for cell lysis. number of leaves were scored positive by PCR than by visual symptom $(P=0.0151)$. Within varieties, this was true for Hill 81 $(P=0.0705)$ and WA7970 $(P=0.0249)$. The proportion of asymptomatic blades positive by PCR was found to differ among cultivars $(P<0.0001)$ but not sampling dates $(P=0.4326)$.

Correlation between PCR detection and isolation of $C$. gramineum. C. gramineum was isolated from 2 of the 18 asymptomatic tillers examined in 2010 (data not shown). The PCR assay and isolation were both positive for one asymptomatic tiller of Stephens sampled 29 April. The $C$. gramineum colony isolated from the upper leaf blade of one asymptomatic tiller of WA7970 sampled 15 April was small compared with other colonies of the same sampling date, and PCR was negative for that blade.

C. gramineum was isolated from the lower leaves of all symptomatic tillers sampled in 2010 (not shown). In four of nine tillers from Stephens, $C$. gramineum was present in young, asymptomatic leaves, as indicated by both isolation and PCR (Table 3). $C$. gramineum was isolated from young, asymptomatic leaves of five of nine tillers from WA7970 with visual symptoms but PCR was positive for $C$. gramineum in only three of these (Table 3 ). Extension of these results to other winter wheat cultivars was evaluated using six tillers with Cephalosporium stripe symptoms on the lower leaves from each of Brundage 96, Eltan, Finch, and Tubbs 06. C. gramineum was isolated from all symptomatic lower leaf blades and from three of six Brundage 96, two of six Eltan, four of six Finch, and five of six Tubbs 06 asymptomatic upper leaf blades. All leaves with $C$. gramineum confirmed by isolation were positive by PCR, except one each of Brundage 96 and Finch.

\section{Discussion}

We developed a PCR-based assay capable of amplifying a portion of the $C$. gramineum ITS region using as little as $100 \mathrm{fg}$ of $C$. gramineum genomic DNA per $1 \mu \mathrm{l}$ of winter wheat DNA at 300 $\mathrm{ng} / \mu \mathrm{l}$. Like the IGS-derived assay developed by Baaj and Kondo (3) that differentiates $C$. gramineum from fungi of 11 other genera, this assay correctly differentiated $C$. gramineum from other wheat mycoflora. In addition, this assay was shown to correctly differentiate infected from noninfected plants.

Assay parameters were systematically evaluated for consistency of amplification from leaf samples with clearly visible Cepha-

Table 2. Proportion of four plants from five winter wheat cultivars or breeding lines sampled at five dates (a total of 100 plants) scored positive for Cephalosporium stripe by visual and polymerase chain reaction (PCR) methods

\begin{tabular}{llccccc}
\hline Wheat & 6 April 2009 & 20 April 2009 & 4 May 2009 & 18 May 09 & 1 June 2009 & Overall \\
\hline Eltan & $0 / 0$ & $0 / 0$ & $0.25 / 0.25$ & $0.50 / 0.75$ & $0.75 / 0.50$ & $0.30 / 0.30$ \\
Hill 81 & $0 / 0.25$ & $0.25 / 0.25$ & $0.75 / 1.0$ & $1.0 / 1.0$ & $0.75 / 1.0$ & $0.55 / 0.70$ \\
Madsen & $0 / 0$ & $0.50 / 0.50$ & $0.50 / 0.50$ & $0.75 / 0.75$ & $1.0 / 1.0$ & $0.55 / 0.55$ \\
Stephens & $0 / 0$ & $0.50 / 0.50$ & $0.75 / 0.75^{\mathrm{a}}$ & $1.0 / 1.0$ & $0.50 / 0.50$ & $0.55 / 0.55$ \\
WA7970 & $0.25 / 0.75$ & $0.25 / 0.75$ & $0 / 0.25$ & $0.50 / 0.50$ & $0.50 / 1.0$ & $0.30 / 0.65$ \\
Overall & $0.05 / 0.20$ & $0.30 / 0.40$ & $0.45 / 0.55$ & $0.75 / 0.80$ & $0.70 / 0.80$ & $0.45 / 0.55$ \\
\hline
\end{tabular}

${ }^{a}$ One symptomatic leaf was scored negative by PCR and one asymptomatic leaf was scored positive by PCR.

Table 3. Isolation of Cephalosporium gramineum and polymerase chain reaction (PCR) scores for the presence of Cephalosporium gramineum in the asymptomatic upper leaves of tillers with symptoms on the lower leaves sampled from winter wheat 'Stephens' and breeding line WA7970 at three dates in $2010^{\mathrm{a}}$

\begin{tabular}{|c|c|c|c|c|c|c|}
\hline \multirow[b]{2}{*}{ Wheat ${ }^{b}$} & \multicolumn{2}{|c|}{15 April 2010} & \multicolumn{2}{|c|}{29 April 2010} & \multicolumn{2}{|c|}{13 May 2010} \\
\hline & Isolation & PCR & Isolation & PCR & Isolation & PCR \\
\hline \multirow[t]{3}{*}{ Stephens } & - & - & + & + & - & - \\
\hline & + & + & - & - & + & + \\
\hline & - & - & + & + & - & - \\
\hline \multirow[t]{3}{*}{ WA7970 } & - & - & - & - & + & + \\
\hline & + & - & + & - & + & - \\
\hline & - & - & + & + & - & - \\
\hline
\end{tabular}

${ }^{a}$ Positive indicates growth of $C$. gramineum from surface-sterilized tissue on a semiselective medium or a positive PCR reaction and negative indicates no growth or a negative PCR reaction. Each pair of data points within a sampling date represents two plants for a total of 6 plants per sample date and 18 plants per cultivar across sample dates.

b Plants were grown in experimental plots located at the Palouse Conservation Field Station near Pullman, WA and inoculated with oat kernels colonized by C. gramineum (213 kg/ha) in October 2009. 
losporium stripe symptoms. We found that the Takara Bio Inc. Ex Taq DNA polymerase provided consistent amplification without the need for BSA to counteract PCR inhibitors present in the plant extracts. Similarly, an hour-long lysis period during extraction was more important to repeatability than was the method of tissue disruption or a higher total nucleic acid yield.

The PCR assay was able to detect $C$. gramineum in DNA from individual seed and in DNA extracted from 20 seeds ground together. Estimates of the number of $C$. gramineum-infected seed per thousand made by isolation and PCR did not differ statistically in this study. However, there is greater error inherent in the estimates from the PCR method because $C$. gramineum isolation provides an estimate by direct observation of each seed, whereas the PCRbased estimate assumes no more than a single infected seed in a sample of 20. A directly analogous PCR-based method would require single-seed DNA extraction that would likely be prohibitively expensive for most applications.

The likelihood of underestimating the number of infected seed per thousand because a 20 -seed sample contains more than one infected seed depends on the likelihood that any given seed is infected. Although this is unknown, we can use the observed number of positive 20-seed samples as an estimate of the number of infected seed per thousand to calculate the expected number of infected seed in each 20 -seed sample. The probability of obtaining more than one infected seed in a sample of 20 can then be approximated using the cumulative Poisson distribution. Using this method, for the Stephens 2008 seed lot with 1.25 positive 20 -seed samples, we estimate an average of 0.025 infected seed out of 20 and a probability of 0.0003 that a positive 20-seed sample contained more than one infected seed. For the WA7970 seed with 5.75 positive samples there should be an average of 0.115 infected seed per 20 -seed sample and a probability of 0.0061 that a positive sample contained more than one infected seed. In the worst case, less than one estimate in a hundred would be downwardly biased by obtaining more than a single infected seed in a 20 -seed sample. The utility of PCR-based diagnosis of $C$. gramineum infected seed using bulk DNA extractions of 20-seed lots will depend on whether this level of uncertainty is acceptable. It may be possible, with more advanced visualization techniques, to use the PCR assay to identify a single infected seed in samples of 100 or more. However, this would increase the uncertainty on any estimate of infected seed per thousand.

The estimates of $0.13 \%$ of Stephens and $0.58 \%$ of WA7970 seed infected with $C$. gramineum were within the previously reported range of 0 to $0.88 \%$ for field-grown seed from inoculated plots (16). Interestingly, tolerant WA7970 had a higher percent infected seed than did susceptible Stephens $(P=0.03)$ but this may be due to chance. In Murray's (16) investigations, 12 cultivars did not differ significantly in percent infected seed. Murray (16) noted a nonsignificant trend of increased seed infection with increased disease severity but at least one tolerant cultivar, 'Nugaines', exhibited low disease incidence and severity with a relatively high $(0.51 \%)$ seed infection rate. The PCR-based assay described here was as effective as the isolation method at detecting seed infection by $C$. gramineum in both the tolerant and susceptible winter wheat cultivars.

The PCR assay was able to detect $C$. gramineum in winter wheat leaf blades without visible symptoms of Cephalosporium stripe. No false-positive PCR results were observed in 72 leaves also tested by isolation on semiselective media. The symptoms of Cephalosporium stripe disease in wheat seedlings lag 5 to 7 days behind $C$. gramineum invasion of the leaf blade under controlled conditions (29). During this time, the fungus is only sparsely present in the xylem vessels $(15,29)$. It appears that the amount of $C$. gramineum present in asymptomatic leaves is often sufficient for detection by PCR. However, six false-negative PCR results were obtained from asymptomatic leaf blades also tested by isolation on semiselective media. Therefore, the PCR assay appears to be less sensitive than isolation for detecting $C$. gramineum in apparently healthy plants. Balancing this, PCR results were ob- tained within 2 days of sampling while isolation required a minimum of 14 days.

The false negatives confirmed by $C$. gramineum isolation were observed in Cephalosporium stripe-tolerant WA7970 and Finch and intermediate Brundage 96. In contrast, PCR results for highly susceptible Stephens and Tubbs 06 were completely consistent with isolation results. Rahman et al. (21) suggested that tolerant winter wheat cultivars may be less sensitive to the Graminin A toxin produced by $C$. gramineum and, thus, exhibit less severe disease symptoms when infected. Morton et al. (15) observed that susceptible winter wheat cultivars accumulated greater amounts of conidia in primary tiller nodes than did resistant cultivars. Consequently, a greater proportion of infected but asymptomatic plants may occur in tolerant cultivars but they may contain less pathogen biomass than asymptomatic plants of susceptible cultivars. Thus, the PCR assay may be more effective at diagnosing Cephalosporium stripe disease in susceptible than in tolerant cultivars.

There were other possible causes of false-negative PCR results in these experiments. The DNA was degraded in two samples from 2009, preventing PCR amplification. Where DNA quality was sufficient, reasons for the failure to detect $C$. gramineum may include poor yield of fungal DNA within the total DNA extract or unusually high levels of PCR inhibitors. False negatives due to these causes were anticipated and efforts to avoid them included notation of relative severity of symptoms, a 1-h incubation time for cell lysis during DNA extraction, and uniform dilution of template DNA prior to PCR. In practice, assay of multiple samples from a suspect field would greatly reduce the likelihood of a false-negative diagnosis for Cephalosporium stripe.

Like the method presented by Baaj and Kondo (3), the PCR assay presented here is accurate, sensitive, and reliable for diagnosing $C$. gramineum infection in winter wheat. Furthermore, and unlike Baaj and Kondo (3), the method presented here has been validated for use in detecting $C$. gramineum in both wheat leaf tissue and seed. Baaj and Kondo's primers amplify an approximately 1,880-bp product, whereas our primers amplify a 496-bp fungal genomic DNA product. The availability of different methods could be useful for creating multiplex assays for systemic fungal infections by the addition of primers specific to other fungi and with a similar annealing temperature but different amplicon size. It may also be possible to convert this assay into a quantitative measure of $C$. gramineum infection using a real-time PCR protocol. The ability to obtain estimates of seed infection rate comparable with those from isolation on semiselective medium but in a shorter period of time may make the PCR assay advantageous for research into $C$. gramineum infection of seed. Likewise, characterization of the ability of this assay to diagnose Cephalosporium stripe in leaf tissue at various stages of winter wheat development in comparison with isolation and visual scoring methods suggests that the PCR method has unique potential for the study of plant-pathogen interaction.

\section{Acknowledgments}

We thank the Washington Grain Alliance and O. A. Vogel Wheat Research Fund for their financial support.

\section{Literature Cited}

1. Anderegg, J. C., and Murray, T. D. 1988. Influence of soil matric potential and soil $\mathrm{pH}$ on Cephalosporium stripe of winter wheat in the greenhouse. Plant Dis. 72:1011-1016.

2. Arneson E., and Stiers, D. L. 1977. Cephalosporium gramineum: a seedborne pathogen. Plant Dis. Rep. 61:619-621.

3. Baaj, D. W., and Kondo, N. 2011. Genotyping Cephalosporium gramineum and development of a marker for molecular diagnosis. Plant Pathol. 60:730738. Online publication. doi:10.1111/j.1365-3059.2011.02429.x

4. Bailey, J. E., Lockwood, J. L., and Wiese, M. V. 1982. Infection of wheat by Cephalosporium gramineum as influenced by freezing of roots. Phytopathology 72:1324-1328.

5. Blank, C., and Murray, T. D. 1998. Seed transmission of Cephalosporium gramineum in winter wheat. (Abstr.) Phytopathology 88:S106.

6. Bruehl, G. W. 1956. Cephalosporium stripe disease of wheat in Washington. Phytopathology 46:178-180.

7. Bruehl, G. W. 1957. Cephalosporium stripe disease of wheat. Phytopath- 
ology 47:641-649.

8. Douhan, G. W., and Murray, T. D. 2001. Infection of winter wheat by $\beta$ glucuronidase-transformed isolate of Cephalosporium gramineum. Phytopathology 91:232-239.

9. Dugan, F. M., and Peever, T. L. 2003. Morphological and cultural differentiation of described species of Alternaria from Poaceae. Mycotaxon 93:650-656.

10. Hibbett, D. S. 1992. Ribosomal RNA and fungal systematics. Trans. Mycol. Soc. Jpn. 33:533-556

11. Johnston, R. H., and Mathre, D. E. 1972. Effect of infection by Cephalosporium gramineum on winter wheat. Crop Sci. 12:817-819.

12. Jones, J. B., Jones, D. J., Roane, C. W., and Tillman, R. W. 1980. Cephalosporium stripe of cereals. Plant Dis. 64:325.

13. Mathre, D. E., Johnston, R. H., and McGuire, C. F. 1977. Cephalosporium stripe of winter wheat: pathogen virulence, sources of resistance, and effect of grain quality. Phytopathology 67:1142-1148.

14. Mathre, D. E., and Johnston, R. H. 1990. A crown barrier related to Cephalosporium stripe resistance in wheat relatives. Can. J. Bot. 68:1511-1514.

15. Morton, J. B., Mathre, D. E., and Johnston, R. H. 1980. Relation between foliar symptoms and systemic advance of Cephalosporium gramineum during winter wheat development. Phytopathology 70:802-807.

16. Murray, T. D. 2006. Seed transmission of Cephalosporium gramineum in winter wheat. Plant Dis. 90:803-806.

17. Neergard, P. 1977. Seed Pathology, Vol. 1 \& 2. Wiley, New York.

18. Nierenberg, H. I. 1981. A simplified method for identifying Fusarium spp. occurring on wheat. Can. J. Bot. 59:1599-1609.

19. Nisikado, Y., Matsumoto, H., and Yamauti, K. 1934. Studies in a new Cephalosporium, which causes the stripe disease of wheat. Ber. Ohara Inst. Landwirtsch. Forsch. Kurashiki 6:275-306.

20. Presting, G. C., Smith, O. P., and Brown, C. R. 1995. Resistance to potato leafroll virus in potato plants transformed with the coat protein gene or with vector control constructs. Phytopathology 85:436-442.

21. Rahman, M., Mundt, C. C., Wolpert, T. J., and Riera-Lizarazu, O. 2001. Sensitivity of wheat genotypes to a toxic fraction produced by Cephalosporium gramineum and correlation with disease susceptibility.
Phytopathology 91:702-707.

22. Richardson, M. J., and Jones, W. J. 1970. An estimate of the loss of yield caused by Cephalosporium gramineum in wheat. Plant Pathol. 19:138-140.

23. Saleh, A. A., and Leslie, J. F. 2004. Cephalosporium maydis is a distinct species in the Gaeumannomyces-Harpophora species complex. Mycologia 96:1294-1305.

24. Specht, L. P., and Murray, T. D. 1989. Sporulation and survival of conidia of Cephalosporium gramineum as influenced by soil $\mathrm{pH}$, soil matric potential and soil fumigation. Phytopathology 79:787-793.

25. Specht, L. P., and Murray, T. D. 1990. Effects of root wounding and inoculum density on Cephalosporium stripe of winter wheat. Phytopathology 80:1108-1114.

26. Stiles, C. M., and Murray, T. D. 1996. Infection of field-grown winter wheat by Cephalosporium gramineum and the effect of soil $\mathrm{pH}$. Phytopathology 86:177-183.

27. Vásquez-Siller, L. M. 2004. Molecular detection of Cephalosporium gramineum in winter wheat seed and cultural factors affecting seed infection. Ph.D. dissertation, Washington State University, Pullman.

28. Vilgalys, R. J., and Johnson, J. L. 1987. Extensive genetic divergence associated with speciation in filamentous fungi. Proc. Natl. Acad. Sci. USA 84:2355-2358.

29. Weise, M. V. 1972. Colonization of wheat seedlings by Cephalosporium gramineum in relation to symptom development. Phytopathology 62:10131018.

30. Weising, K., Nybom, H., Wolff, K., and Meyer, W. 1995. DNA isolation and purification. Pages 51-54 in: DNA Fingerprinting in Plants and Fungi. CRC Press, Boca Raton, FL.

31. Wetzel, H. C., III, Esvelt Klos, K., and Murray, T. D. 2009. Reaction of winter wheat cultivars and breeding lines to Cephalosporium stripe, 2008. Plant Dis. Manage. Rep. 3:CF042. Online publication. doi:10.1094/ PDMR03.

32. Wetzel, H. C., III, Evans, J. C., Esvelt Klos, K., and Murray, T. D. 2010. Reaction of winter wheat cultivars and breeding lines to Cephalosporium stripe, 2009. Plant Dis. Manage. Rep. 4:CF027. Online publication. doi:10.1094/ PDMR04. 